\title{
Current Human Impact on Antarctic Seabed Environment and International Law
}

\author{
Yana Evgenyevna Brazovskaya and Gulnara Flurovna Ruchkina
}

Antarctica is perhaps the most mysterious and breath-taking continent of our planet by its extreme natural conditions and the absence of a native human population. Located 'opposite the Arctic', it is the world's largest and coldest desert, the highest continent of the Earth, and, at the same time, a mostly unknown and still under-researched area. Remoteness, permanent glacial cover of the continent, and exceptionally severe weather conditions have apparently also influenced the legal status of the Antarctic territories and the legal regime of their use. Indeed, the 1959 Antarctic Treaty ${ }^{1}$ which together with related protocols and conventions form the Antarctic Treaty System (ATS), affirms in its Article I.1 that 'Antarctica shall be used for peaceful purposes only.' Parties to the Treaty have, so to speak, cut the southern polar region ${ }^{2}$ off of the possible proliferation of nuclear weapons and conduct of any military activities. ${ }^{3}$ The parties also excluded the possibility of regulating the development of industrial development of mineral resources of the Antarctic. However, the Antarctic Treaty aims to facilitate scientific research in Antarctica. ${ }^{4}$

The level of political tensions in the Arctic is much higher than that observed in the Antarctic, with only attempts to raise Antarctic delimitation claims. However, the constant pressure on worldwide natural resources sheds a new light on the more remote areas, including Antarctica, with the subjacent race to claim jurisdiction over those. A first example relates to access to fresh water. A growing number of research shows that water scarcity represents a major threat on vital resources for mankind, threatening the life

1 The 1959 Antarctic Treaty was signed in Washington and entered into force on June 23, 1961, after being signed by the 12 nations that were the Treaty's initial parties. Since then, other nations have acceded the Treaty, which now counts 53 parties.

2 Which covers almost 50 million square kilometres, or $10 \%$ of the planet's area, and the mainland is twice the size of Europe. Source: https://ria.ru/spravka/20141130/1035503295.html.

3 Article I.1 and V.1, the 1959 Antarctic Treaty.

4 Articles II, the 1959 Antarctic Treaty. 
conditions of hundreds of millions of people around the world. ${ }^{5}$ This has led to increased competition for scarce resources, which can both exacerbate old security dilemmas and create new ones. ${ }^{6}$ Access to ice reserves in Antarctica will open almost 80 percent of total fresh water reserves on the planet. A second natural resource is catching attention in the Antarctic. It is highly probable that various kinds of mineral raw materials are present in the interior of Antarctic. Unlike solid minerals, the forecast of hydrocarbon resources in the Antarctic is mainly based on the materials of structural-tectonic zoning, carried out using remote geophysical methods, paleotectonic reconstructions and geohistorical analysis. According to scientists, there may be about 900 significant crude ore deposits in Antarctica. Despite the fragmentation and small size of the overglacial outcrops of the bedrock even in relatively naked mountainous areas of Antarctica, they found many manifestations of ore and non-metallic minerals, representing weak mineralization. ${ }^{7}$ According to British scientists, there are coal deposits in the depths of the sixth continent, and American scientists insist that Antarctica has oil and gold. ${ }^{8}$ The presence of hydrocarbon reserves ${ }^{9}$ in the seabed may therefore reasonably be assumed, with estimated $35^{-51}$ billion tons of conditional fuel to be present on the self of Antarctic seas. ${ }^{10}$ Those are only two examples in an area which is the least explored of the two circumpolar regions.

It is believed that Antarctica is the only continent with no history of human habitation," ${ }^{11}$ but at present this glacial region is the one most 'densely

5 A. Kushnarenko, 'Lack of Fresh Water: Problems and Solutions,' The W\&L, 28.05.2015. Source: <http://thewallmagazine.ru/lack-of-fresh-water/>.

6 Speech of UN Secretary-General Ban Ki-moon at the Security Council session in 2011. Source: http://www.un.org/ru/sections/issues-depth/water/index.html.

7 G.E. Grikurov, G.L. Leichenkov, E.V. Mikhalsky, A.V. Golynsky, V.N. Masolov 'Antarctic mineral resources: geological preconditions and perspectives of development' Source: http:// evgengusev.narod.ru/vniio/grikurov-20oo.pdf. ITAR-TASS. 'Antarctic:history and problems'.Source:https://tass.ru/spravochnaya-informa ciya/628230.

9 The forecast of hydrocarbon resources of Antarctica is based mainly on the materials of structural tectonic zoning by remote geophysical methods, paleotectonic reconstructions, and geo-historical analysis.

10 Antarctica: History and Problems, 03.07.2013. TASs: http://tass.ru/spravochnaya-informa ciya/62823o.

11 Linda Nowlan. Arctic Legal Regime for Environmental Protection. IUCN Environmental Policy and Law Paper No. 44, p. 41. 
populated' by scientists. ${ }^{12}$ The lack of native human population has not prevented states from claiming sovereignty over the Antarctic areas. At least seven countries have put forward territorial claims: Argentina, Australia, Chile, France, New Zealand, Norway and the United Kingdom. ${ }^{13}$ However, in the view of the present authors, these claims are more of a historical nature. Russia and the United States have reserved their rights; they consider themselves pioneers of Antarctica, entitled to requiring the sovereignty of the territory. ${ }^{14}$ It should be noted that the claimant nations did not abandon their territorial claims for Antarctica. For instance, in 2004, Australia sent a request to the UN Commission on the Limits of the Continental Shelf for the Antarctic shelf adjacent to the 'Australian Antarctic Sector,' which, incidentally, was rejected. ${ }^{15}$

The question of the islands and associated continental shelf, located between $40^{\circ}$ and $60^{\circ}$ south latitude is disputable respectively, whichever the boundary of the Southern Ocean is: the Antarctic Circumpolar current (area of $40^{\circ}$ south latitude) or the area regulated by the Antarctic Treaty (area of $60^{\circ}$ south latitude).

Both the prospects of accessing in rich natural resources and the effects of climate change have the potential to revive old and new claims. Indeed, the effects of climate change in Antarctica will mainly result in a warmer climate in that part of the Earth, according to scientists. Because of global warming and sea level rise, many of the largest megacities of the planet, as well as small island nations, will disappear. If all glaciers of the mainland melt, Antarctica will become an archipelago (a chain of islands) ${ }^{16}$ and the territorial claims issue will appear in much brighter colours.

12 Approximately 29 nations operate seasonal (summer) and year-round stations on the continent and in the coastal zone. The number of scientists engaged in scientific research on the continent and nearby islands varies from around 4,000 in summer, and up to 1,000 in winter; in addition, about 1,00o specialists, including ship crews, are located in the waters adjacent to the continent. As of 2004, the largest number of researches during the summer season was deployed by the USA (about 1,100), Russia, Chile, and Argentina (300), Australia (200) and the United Kingdom (192). During winter, it was Russia, Chile, and Argentina (approximately 200) and the USA (120-130). There are 42 year-round stations in Antarctica (6 belong to Russia and Argentina, 4 to Australia and Chile, 3 to the USA and 2 to the UK).

13 T.B. Mordvinova. A.S. Skaridov, M.A. Skaridova. Polar Law. M., Justitia, 2017, at 200.

14 Who and why is interested in Antarctica? June 07, 2017. Source: http://www.profi-forex .by/news/entry5000037141.html.

15 The United Kingdom, Argentina, New Zealand, and South Africa may submit similar requests for the Southern Ocean shelf. See Recommendations (9 April 2008) Source: http://www.un.org/Depts/los/clcs_new/submissions_files/submission_aus.htm.

16 Antarctic Mainland, 24.06.2017. Source: http://mirplaneta.ru/materik-antarktida -opisanie-relef-klimat.html. 
At the present time, the coastal contours of Antarctica are above the Arctic coastline. They are in fact static coastal fast ice, forming ice fronts almost all over, whose height above sea level varies from a few to dozens of meters. Of the total length of the Antarctic coastline (30,00o km), 92 percent are ice banks and only 8 percent are rocky shores. The Southern Ocean is a deep-sea basin. Areas with depths of 3,000 meters occupy about 77 percent of the total area of the ocean. Due to the huge glacial load, the Antarctic shelf is immersed to a depth of up to 500 meters and stretches in a relatively narrow strip, about 280 kilometres on the average. ${ }^{17}$

It should be noted that the international agreement on the delimitation of Antarctic spaces does not exist, as it does for the Arctic. According to A. Skaridov, the international legal doctrine has at least three points of view in this regard, namely that: (i) the areas are outside the jurisdiction of any country, to which the rules of international law apply; (ii) they are areas of joint use of countries (by condominium theory they should be managed by all countries with the assistance of an international organization); (iii) division into sectors to be fully owned by various countries. ${ }^{18}$

While the situation is relatively straightforward in the first two points of view, the theory of sectoral delineation may be less complicated than foreseen to apply in Antarctica. It should be noted that most of the Arctic countries deny the sectoral delineation, but this does not necessarily mean that the situation in Antarctica will cause a similar response, ${ }^{19}$ taking into account the previously mentioned claims of the sectoral nature. In order to consolidate rights to a certain sector, justifications such as geographical proximity, right of discovery, or continuous control or occupation of the territory are often referred to. ${ }^{20}$ On the one hand, the division of Antarctica into sectors is the simplest and most acceptable way to solve the problem of territorial claims, but on the other hand it is strongly criticized by many lawyers and politicians. For example, US lawyer R. Hayton is of the opinion that geographical proximity, or in other words 'attraction', does not give countries any rights to own

17 Ice Navigation Conditions in the Southern Ocean. A.A. Romanov. Marine Meteorology and Related Oceanographic Activities, Issue No. 35//WMO/TD-No. 783.

18 A. Skaridov, Maritime Law. Moscow, URAIT, 2014, at 167-169. See chapter 5 of this book, A. Skaridov, 'The seabed in the High North - How to address conflicts?'.

19 Although the Arctic and Antarctic regions are similar in many ways, there are also significant differences between them. The Arctic is an ocean surrounded by continents, while Antarctica is a continent surrounded by oceans.

20 N. V Ilyushina, 'Problem of Territorial Division of Antarctica'Topical Issues of Current International Relations, 2015. Available at <https://cyberleninka.ru/article/n/problema -territorialnogo-razdela-antarktiki>. 
Antarctica. ${ }^{21} \mathrm{He}$ finds it impossible that the rest of the community of nations may be willing to cede all rights to uninhabited lands that may be of strategic importance.

The unilateral establishment of a sectoral division of Antarctica is contrary to the interests of most countries of the world, but assuming that the 1959 Antarctic Treaty ceases to exist and the continent is divided by a sectoral principle, countries will need to measure the breadth of the territorial sea, the Exclusive Economic Zone (EEZ), that is, to resolve the issue of maritime boundaries, and here additional difficulties may arise.

Indeed, in accordance with Article 5 of the United Nations Convention on the Law of the Sea of 1982 (UNCLOS), the normal baseline for measuring the breadth of the territorial sea is the low-water line along the coast. ${ }^{22}$ Pursuant to Article 7 of the same Convention, straight baselines should also connect the appropriate points on the shoreline. It is noteworthy that this Convention does not determine the notions of 'shore' and 'shoreline'.

The UN technical expert team determine the shore as a line of contact of the aquatic environment and the land. Since in the establishment of maritime borders, polar borders included, the key is the legality of the definition of the reference base, the definition of what should be understood under the shore, takes a fundamental importance. However, it is not clear what should be understood under 'land' or 'shore' in Antarctic conditions as there is no physically defined concept of 'shore.'23

Ice as a physical category may have different origins, but from a legal standpoint, ice mobility is probably its most important hydrographic characteristic. If the outer edge of the glacier, i.e. the line where two ecosystems with different physical characteristics get in contact, is virtually static, that is, not subject to seasonal fluctuations, it can be considered as a coastline. So, the edge of such geomorphological phenomenon as a multi-year glacial fast ice, or the edge of a hummock attached to the shore or fast ice, in case they are naturally connected to the coast and the lack fluctuations due to seasonal cycles may be considered in the polar areas as a coastline in the sense that is applies to the provisions of Articles 5, 7 and 47 of the 1982 UNCLOS to such a line. ${ }^{24}$

Unfortunately, the 1982 UNCLOS did not take into account the peculiarities of establishing borders in constantly ice-covered polar regions. Only in its

21 R.D. Hayton, 'The Antarctic Settlement of 1959', American Journal of International Law (1960: 54), No. 2. at 359-36o.

22 For a review of the international process, see chapter 4 of this book, A. Brekke, 'Setting boundaries: Experiences from Norway'.

23 Law of the Sea: a textbook for masters/A.S. Skaridov. - 2nd edition as extended and amended. - M.: URAIT Publishing House, 2012.167 pages.

Ibid. P. 168. 
Article 234 it indicates that coastal countries have the right to adopt and enforce non-discriminatory laws and regulations for the prevention, reduction and control of marine pollution from vessels within the limits of the EEZ, where particularly severe climatic conditions and the presence of ice covering such areas for most of the year create obstructions or exceptional hazards to navigation, and pollution of the marine environment could cause major harm to or irreversible disturbance of the ecological balance.

However, the text of the Convention contains provisions which may be considered as an indirect confirmation of the legality of accounting for static ice massifs, which are a continuation of the shore, as a reference point for the outer limits of maritime spaces. For example, natural formations such as reefs have almost the same geophysical dynamics in the south as ice massifs in the north. For the purpose of computing the ratio of water to land, land areas may include waters lying within the fringing reefs of islands and atolls, including that part of a steep-sided oceanic plateau which is enclosed or nearly enclosed by a chain of limestone islands and drying reefs lying on the perimeter of the plateau (paragraph 7, Article 47 of UNCLOS.) The 1982 Convention also reads that in the case of islands situated on atolls or of islands having fringing reefs, the baseline for measuring the breadth of the territorial sea is the seaward lowwater line of the reef, as shown by the appropriate symbol on charts officially recognized by the coastal state.

Thus, the placement of points defining the position of the baselines on the outer edge of the foundation of the coastal fast ice may be found not inconsistent with the provisions of UNCLOS, and it may be assumed that the difficulty of delimiting maritime and submarine areas near the Antarctic continent will be related to the uncertainty of the definition of the datum, i.e. baselines.

In addition, with regard to the delimitation of the continental shelf in Antarctica, it should be noted that, under the 1958 Convention on the Continental Shelf, the term 'continental shelf' is used as referring to the seabed and subsoil of the submarine areas adjacent to the coast but outside the area of the territorial sea (Article 1 (a)). But according to UNCLOS, the 'continental shelf of a coastal state' comprises the seabed and subsoil of the submarine areas that extend beyond its territorial sea throughout the natural prolongation of its land territory (Article $76(1)$ ).

Taking into account the conventional position, it is possible to speak about continental shelf of a coastal state only. The institution of continental shelf is inseparably tied to the institution of territorial sea, hence legally there is no such thing as continental shelf of international territory.

That is, by implication of the 1958 Convention and the 1982 Convention, the continental shelf of a coastal state begins where the bottom of its territorial 
sea ends. Therefore, due to the fact that no state has its territorial sea washing Antarctica, it is not possible to discuss any continental shelf of Antarctica.

\section{Exploitation of Mineral Resources from the Seabed in the Antarctic}

To date, the legal regime of Antarctic regions is formed by four basic agreements as part of the ATs:

- The Antarctic Treaty, 1959;

- Protocol to the Antarctic Treaty on Environmental Protection, 1991 (Protocol on Environmental Protection to the Antarctic Treaty (Madrid Protocol);

- Convention for the Conservation of Antarctic Seals, 1972;

- Convention on Conservation of Antarctic Marine Living Resources, 1980 (CCAMLR).

At the time of signing the Antarctic Treaty, the member countries ${ }^{25}$ were mainly focused on: security issues (in the Treaty, the parties secured their renunciation of claims to territorial sovereignty (Article IV)); the prohibition of any measures of a military nature, except for the use of military personnel or equipment for scientific research or for any other peaceful purpose (Article I); and the freedom of scientific investigation (Article II). But after the 1998 Madrid Protocol entered into force, some scholars believe that the rules governing the legal regime of Antarctica have essentially acquired an 'ecological vector. ${ }^{26}$

The analysis of the above rules allows to assert that international law does not regulate the industrial development of mineral resources in Antarctica. In accordance with Article 7 of the 1991 Protocol, 'any activity relating to mineral resources, except for scientific research, shall be prohibited.' However, scientific research in this field are carried out on regular basis, despite the fact that Antarctica is not the best terrain for the placement of drilling rigs. For the purpose of exploration and development of possible mineral deposits, new techniques are being implemented, which will entail the development of

25 The Parties to the Treaty are 50 countries constituting about two thirds of the world population, and 28 countries have become Antarctic Treaty Consultative Parties (ATCP).

26 At the 4oth Consultative Meeting, the participants agreed and adopted documents and decisions on the practice of "ecological expeditions" in Antarctica, which implies that research activities in Antarctica is based on the principles of friendly and careful attitude to the environment, i.e. scientists and explorers will strive to minimize the negative impact of their activities on the polar environment. 
large deposits in previously undeveloped regions, such as exemplified by the ice Lake Vostok. ${ }^{27}$

Sooner or later, the question of industrial extraction of Antarctic natural resources will be raised, which, given the 'frozen' territorial claims of countries, would require the adoption of a special legal regime for continental Antarctic shelf as an alternative to the continental shelf regime in the sense of the 1982 UNCLOS. Thus, we may state that the established legal regime of the use of Antarctic areas does not solve long-arisen problems of activity on the continent. Recent advances in science and technology, and the overall development of productive forces have made Antarctica more accessible, and the resources of the continent arouse high interest in the region.

The situation in Antarctica is complicated by the fact that the mainland part is covered by an insuperable ice sheet. Consequently, the development of offshore fields in Antarctica will be obstructed by icebergs and the work would take place at a depth of more than 500 meters. ${ }^{28}$ The practicability of safe transportation of oil from Antarctica via pipelines is also questionable. Norwegian companies have begun to implement underwater mining complexes in the Arctic. Antarctica in turn has its climatic features, plus it is at a considerable distance from the states interested in mineral resources. According to experts of the Research Institute of Oceanology, currently there are no such technologies that can be effectively used in Antarctica. ${ }^{29}$ It is believed that the extraction of Antarctica oil and gas is mostly hampered by super-harsh climatic conditions on the ice continent, which also affects the profitability of the company.

International legal regulation of the Antarctic mineral resources regime was supposed to be governed by the 1988 Convention on the Regulation of Mineral Resources of Antarctica, which was to establish that the search, exploration, and development of Antarctic mineral resources should be exclusively in accordance with the said Convention. The main idea and purpose of the Convention is that the development of resources should not cause any harm to the natural environment. It is controlled by the establishment of conditions and procedures for the development and production of mineral resources.

According to the 1988 Convention, the limit of its distribution is the entire continent of Antarctica and all Antarctic islands, including all ice shelves,

27 In Antarctica there are 89 scientific polar stations and bases of various countries, which conduct seasonal (summer) and year-round scientific (including biological, geographical, geological and meteorological) research on the continent and its coastal area.

28 There is oil in Antarctica, but it is impracticable to extract it. Alexander Danilov, Deputy Director (Research), Arctic and Antarctic Research Institute (AANIA), 24.01.2012. Source: RIA Novosti https://ria.ru/eco/20120124/547701814.html.

Ibid. 
south of 6o degrees south latitude and the seabed and subsoil of adjacent offshore areas up to the deep seabed (up to the limits of the continental shelf).

In view of the special importance of Antarctica as a natural reserve for the development of science, the adoption of the 1988 Convention caused a negative reaction by the international community, ${ }^{30}$ which expressed concerns about the possibility of industrial development of Antarctic mineral resources and the related serious threats this may cause to the environment. ${ }^{31}$

\section{Environmental Protection of Antarctic Seabed Resources}

In order to rectify the situation, as well as to improve the protection of Antarctic ecology and its dependent and related ecosystems, and to increase the guaranteed nature of the use of Antarctic region exclusively for peaceful purposes and to improve the ATs, a special Antarctic Treaty Consultative Meeting at the XI session in 1991 adopted The Protocol on Environmental Protection $^{32}$ to the Antarctic Treaty.

It should be noted that the Protocol does not change and does not amend the 1959 Treaty, but only complements it (Section 4, Art. 4).

The protection of the Antarctic environment and its dependent and associated ecosystems should be one of the main factors in the planning and implementation of any activity in the Antarctic Treaty area (Article 3 of the 1998 Protocol).

To achieve these goals, special protective measures should be planned and developed in Antarctica to avoid anthropogenic environmental impact, including through the prohibition of any activity on the industrial development of mineral resources. An exception is provided for scientific research (Article 7).

The protocol prioritized the provision that 'The protection of the Antarctic environment and dependent and associated ecosystems shall be fundamental considerations in the planning and conduct of all activities in the Antarctic Treaty area'. In order to achieve these objectives, special activities should be planned and developed in Antarctica in order to avoid human impact on the environment, in particular by prohibiting any activity for industrial

\footnotetext{
30 This position was outlined in a resolution adopted by the UN General Assembly at its 43th session in 1988, which expressed "deep regret" in connection with the adoption of the 1988 Convention.

31 Modern International Law of the Sea and Practice of its Application. Monograph. - M.: Nauchnaya Kniga. 2003. -236 pp.

32 So-called Madrid Protocol.
} 
development of mineral resources, with exception provided for scientific research. ${ }^{33}$

\section{$5 \quad$ Concluding Remarks}

Today, the issues of legal regulation of international relations, in particular those directly related to the use of natural resources, take special importance. The solution to these problems is in fact closely linked to the crucial issue of our era, i.e. the struggle for peace. It is in connection with the use of resources that the interests of different countries clash most acutely. The way these interests are reconciled depends largely on whether international cooperation will be established or strengthened; if not, an environment fraught with dangerous aggravation of relations will grow. ${ }^{34}$

A possible solution to the problem of delimitation of maritime areas and therefore of possible claims by different countries for marine resources including the seabed may be the adoption of a special legal regime for the continental shelf of Antarctica and conclusion of bilateral agreements on the delimitation of maritime areas.

It is also likely that Antarctic mineral resources will be considered as a very remote reserve for future generations for a long time. In the near future, there is no reason to expect that the priority of scientific geological and geophysical research will be undermined by unilateral infringement or early lifting of the moratorium on geological prospecting and mining work. Nevertheless, the attention given to the potential resources of Antarctica under the influence of the oil crisis of the early 1970s, leading to the forced elaboration of the International Mineral Exploration Convention, frozen in 1991, indicates the severity of the problem, which for the duration of the moratorium may become more geopolitical than economic. ${ }^{35}$

Most likely, countries with territorial claims in Antarctica, industrialized countries that do not have their own resource base (Japan, Germany) or

33 It is well known that at fluctuations in the number of populations or in biodiversity of communities of living organisms, a negative role can be played not only by man-made impacts, but also by problems of climate and food potential changes, viral diseases of organisms caused by impacts of transboundary transfers in the ocean and atmosphere, or large-scale natural disasters (volcanism, earthquakes, collapse of icebergs, tsunamis etc.).

34 V.A. Avkhadeev Issues of Current Territorial Claims in Antarctica ... "Law of the Sea" web magazine, 2008.

35 Mineral Resources of the Arctic: Geological background and development prospects. G.E. Grikurov, G.L. Leichenkov, E.V. Michalski, A.V. Golynsky, V.N. Masolov. // Exploration and protection of subsoil. 2000. No. 12. 
whose strategic line is for the conservation of national resources (USA), will be enhancing the scope of research work aimed at revealing the prospects of the region's mineral resources and strengthening their presence on the continent through research, and establishment of stations and bases. 